\section{Enamel proteins and proteases in Mmp20 and Klk4 null and double-null mice}

Yamakoshi Y, Richardson AS, Nunez SM, Yamakoshi F, Milkovich RN, Hu JC-C, Bartlett JD, Simmer JP. Enamel proteins and proteases in Mmp20 and Klk4 null and double-null mice.

Eur J Oral Sci 2011; 119 (Suppl. 1): 206-216. (C) 2011 Eur J Oral Sci

Matrix metalloproteinase 20 (MMP20) and kallikrein-related peptidase 4 (KLK4) are thought to be necessary to clear proteins from the enamel matrix of developing teeth. We characterized Mmp2O and Klk4 null mice to better understand their roles in matrix degradation and removal. Histological examination showed retained organic matrix in Mmp20, Klk4, and Mmp20/Klk4 double-null mouse enamel matrix, but not in the wild-type. X-gal histostaining of $\mathrm{Mmp} 20$ null mice heterozygous for the Klk4 knockout/lacZ knockin showed that Klk4 is expressed normally in the Mmp20 null background. This finding was corroborated by zymogram and western blotting, which discovered a 40-kDa protease induced in the maturation stage of Mmp20 null mice. Proteins were extracted from secretory-stage or maturation-stage maxillary first molars from wild-type, Mmp20 null, Klk4 null, and Mmp20/Klk4 double-null mice and were analyzed by SDS-PAGE and western blotting. Only intact amelogenins and ameloblastin were observed in secretory-stage enamel of Mmp20 null mice, whereas the secretory-stage matrix from Klk4 null mice was identical to the matrix from wildtype mice. More residual matrix was observed in the double-null mice compared with either of the single-null mice. These results support the importance of MMP20 during the secretory stage and of KLK4 during the maturation stage and show there is only limited functional redundancy for these enzymes.
Yasuo Yamakoshi ${ }^{1}$, Amelia S. Richardson ${ }^{1}$, Stephanie M. Nunez ${ }^{1}$, Fumiko Yamakoshi ${ }^{1}$, Rachel N. Milkovich ${ }^{1}$, Jan C-C. Hu ${ }^{1}$, John D. Bartlett $^{2}$, James P. Simmer ${ }^{1}$

${ }^{1}$ Department of Biologic and Materials Sciences, University of Michigan School of Dentistry, Ann Arbor, MI, USA; ${ }^{2}$ Department of Cytokine Biology, Forsyth Institute and Department of Developmental Biology, Harvard School of Dental Medicine, Cambridge, MA, USA

James P. Simmer DDS, PhD, Department of Biologic and Materials Sciences, University of Michigan Dental Research Laboratory, 1210 Eisenhower PI, Ann Arbor, MI 48108, USA

Telefax: +1-734-9759329

E-mail: jsimmer@umich.edu

Key words: enamel; enamel maturation; kallikrein 4; proteases; proteinases; teeth

Accepted for publication August 2011
Dental enamel forms in two stages. During the secretory stage mineral ribbons lengthen along a mineralization front at the enamel surface $(1,2)$. By the end of the secretory stage the enamel layer has already reached its final dimensions. In the rat incisor about $9 \%$ of the volume and $36 \%$ of the weight of the enamel matrix is mineral, which equals only about $14 \%$ of the mineral present at eruption (3). During the maturation stage, crystals initially deposited during the secretory stage grow thicker and wider. By the end of the maturation stage the mineral comprises about $70 \%$ of the volume and over $90 \%$ of the weight of the enamel matrix, which is more highly mineralized than other mineralized tissues, such as bone and dentin.

Proteins are abundant in secretory-stage and early maturation-stage enamel, but are virtually absent from the late maturation-stage matrix (4). Proteins secreted during the secretory stage are degraded during both the secretory and maturation stages. Enamel protein cleavage products are reabsorbed by ameloblasts and degraded (4-7). There are two major secreted enamel proteases: matrix metalloproteinase 20 (MMP20) (8) and kallikrein-related peptidase 4 (KLK4) (9). These enzymes are necessary for enamel formation, as mutations in
MMP20 (10) and KLK4 (11) cause inherited enamel malformations. A major function of enamel proteases is to facilitate the removal of enamel proteins to free up space within the enamel matrix for the enamel crystallites to grow in width and thickness (12). Several reviews on the roles of proteases in dental enamel formation are available (13-15).

Enamel protein cleavage sites have been characterized for proteins that accumulate in secretory-stage pig enamel, and MMP20 is able to catalyze the same amelogenin $(16,17)$ and ameloblastin $(18,19)$ cleavages in vitro as occur in vivo. Kallikrein-related peptidase 4 cleaves amelogenin at many sites, but the cleavage pattern is different from that produced by MMP20 (20). The amelogenin C-terminus is highly charged relative to the rest of the protein and increases the affinity of amelogenin for hydroxyapatite (21). Matrix metalloproteinase 20 removes the amelogenin $\mathrm{C}$-terminus, suggesting that MMP20 may be necessary to dissociate amelogenin from the crystals. However, cleavages by KLK4 on the $\mathrm{N}$-terminal side of amelogenin also decrease amelogenin binding to hydroxyapatite in vitro (22).

Mmp2O $(23,24)$ and Klk4 (25) null mice both have dramatic enamel phenotypes in which the hypomineral- 
ized enamel undergoes rapid attrition. The enamel in the Mmp20 null mice breaks off at the dentino-enamel junction (DEJ), while the enamel in the Klk4 null mice breaks just above the DEJ, in the deep enamel (26). Mmp20 null mice cover dentin with a rough mineral layer that is generally thin but irregular, and lacks rod and inter-rod organization (27). The enamel in Klk4 null mice has normal thickness and rod organization and is hard at the surface but is progressively less mineralized with depth (27). The enamel layers of both types of null mice retain enamel proteins, but the state of degradation of these proteins has not been characterized. In this study we analyzed the enamel proteins and proteases in wild-type, Mmp20 null, Klk4 null, and Mmp20/Klk4 double-null mouse maxillary first molars during the secretory stage, the maturation stage, and just prior to tooth eruption.

\section{Material and methods}

All procedures involving animals were reviewed and approved by the Institutional Animal Care and Use Program at the University of Michigan.

\section{Mouse breeding}

Wild-type, Klk4 null, and Mmp20 null mice were all in the C57BL/6J background. Mmp20/Klk4 (MK) double-null mice were obtained by crossing Klk4 null mice and Mmp20 null mice. The resulting $\mathrm{Mmp} 2 \mathrm{O}^{+/-} / \mathrm{Klk}^{+/-}$offspring were interbred. Then, $\mathrm{Mmp} 2 \mathrm{O}^{-/-} / \mathrm{Klk}^{+}{ }^{+-}$mice were crossed to yield $M m p 20^{-/-} / K_{k} 4^{-/-}$(MK double null) mice. Homozygous null and double-null mice were interbred to obtain litters of Klk4 null, Mmp20 null, and Mmp20/Klk4 (MK) double-null mice. All mice were fed on soft chow and no variations outside of the dentitions were noted.

\section{Mouse genotyping}

PCR genotyping was performed using genomic DNA obtained by tail biopsy. The following primer pairs were used $\mathrm{Klk}^{+}$allele (5'-AACCTAAGGGACAGGGCAGT and 5'-TGAGGTGGTACACAGGGTCA; 550-bp amplicon); Klk4 $4^{\text {lac } Z}$ allele (5'-TGCCTCCAACCAGATAGGTC and 5'-GACAGTATCGGCCTCAGGAA, 595-bp amplicon) (25); $\mathrm{Mmp}_{20}{ }^{+}$allele (5'-AAGTAGACTGAAGTCAGGAGAGCC and 5'-CTGTAGTGGTGACCCTAGTCATC TT, 545-bp amplicon); and $M m p 20^{-}$allele (5'-CTGCGT CCCCAGACTTTTGATTT and 5'-GCTTTTCATGGCCAGAATGCTCT, 650-bp amplicon) (23).

\section{Histology}

Wild-type, Klk4 null, and Mmp20 null mouse heads at days 5,11 , and 15 were quickly dissected of skin, cut in half, immersed in $5 \%$ paraformaldehyde $+2 \%$ sucrose fixative overnight at $4^{\circ} \mathrm{C}(\mathrm{pH} 7.3)$, and then decalcified at $4^{\circ} \mathrm{C}$ by immersion in 11 of $5 \%$ disodium ethylenediaminetetraacetic acid (EDTA) $+0.8 \%$ paraformaldehyde $(\mathrm{pH} 7.3)$ with agitation (28). Day-5 mice underwent decalcification for $3 \mathrm{wk}$, day-11 mice for $4 \mathrm{wk}$, and day-15 mice for $6 \mathrm{wk}$, with a change of fresh solution every other day. The samples were washed in PBS (135 mM NaCl, 2.7 mM KCl, $4.3 \mathrm{mM}$
$\left.\mathrm{Na}_{2} \mathrm{HPO}_{4}, 1.4 \mathrm{mM} \mathrm{Na} \mathrm{H}_{2} \mathrm{PO}_{4} ; \mathrm{pH} 7.3\right)+0.8 \%$ paraformaldehyde at $4^{\circ} \mathrm{C}$, four to five times (every $0.5-1 \mathrm{~h}$ ), followed by one overnight wash, then dehydrated using a graded ethanol series followed by xylene, embedded in paraffin, sectioned at $5 \mu \mathrm{m}$, stained with Harris Hematoxylin and Eosin (Fisher Scientific, Waltham, MA, USA), and imaged using a Nikon Eclipse TE300 Inverted Microscope, Nikon Digital Sight DS-Ril camera, and NIS-Element Basic Research software (Mager Scientific, Dexter, MI, USA). Objectivity was optimized using a section from a single hemi-maxilla prepared for each figure panel.

\section{Tissue processing for histochemistry}

Mouse heads from days $5,8,11,14$, and 15 were quickly dissected of skin, cut in half, and immersed in $4 \%$ paraformaldehyde fixative $(\mathrm{pH} 7.3)$ overnight at $4^{\circ} \mathrm{C}$, washed in PBS four or five times (every $0.5-1 \mathrm{~h}$ ) at $4^{\circ} \mathrm{C}$, and decalcified at $4^{\circ} \mathrm{C}$ by immersion in 11 of $4.13 \%$ disodium EDTA ( $\mathrm{pH}$ 7.3) with agitation. Day-5 mice underwent decalcification for $3 \mathrm{wk}$, days 8 and 11 mice for $4 \mathrm{wk}$, and days 14 and 15 mice for $6 \mathrm{wk}$, with a change of fresh solution every other day. The samples were washed in PBS at $4^{\circ} \mathrm{C}$ four or five times (every $0.5-1 \mathrm{~h}$ ) followed by one overnight wash, then immersed in 15\% sucrose (for $1-2 \mathrm{~h}$ ) followed by $30 \%$ sucrose (for $3-4 \mathrm{~h}$ ) at $4^{\circ} \mathrm{C}$ for cryoprotection, embedded in Optimal Cutting Temperature compound (OCT) and stored at $-80^{\circ} \mathrm{C}$. The blocks were cryosectioned at $8-\mu \mathrm{m}$ thickness at -20 to $-22^{\circ} \mathrm{C}$ on a Leica cryostat. The slides were stored at $-80^{\circ} \mathrm{C}$ until staining.

\section{X-gal staining}

Slides were removed from $-80^{\circ} \mathrm{C}$ and immediately treated with glutaraldehyde fixative [0.1 M 4-(2-hydroxyethyl)-1piperazineethanesulfonic acid (HEPES), $1.25 \mathrm{mM}$ ethylene glycol tetraacetic acid (EGTA), $2 \mathrm{mM} \mathrm{MgCl}_{2}, 0.5 \%$ glutaraldehyde, $\mathrm{pH}$ 7.3] and then washed three times, for 5 min each wash, with $0.1 \mathrm{M}$ HEPES, $2 \mathrm{mM} \mathrm{MgCl}_{2}(\mathrm{pH}$ 7.3). The slides were stained with $\mathrm{X}$-gal solution $(0.1 \mathrm{M}$ HEPES, $1 \mathrm{mM} \mathrm{MgCl}_{2}, 5 \mathrm{mM}$ potassium ferrocyanide, $5 \mathrm{mM}$ potassium ferricyanide, $2 \%$ Triton $\mathrm{X}-100,1 \mathrm{mg} \mathrm{ml}^{-1}$ $\mathrm{X}$-gal substrate; $\mathrm{pH} 8.0$ ) for $5 \mathrm{~h}$ at $45^{\circ} \mathrm{C}$ and then washed several times in PBS, counterstained with $0.1 \%(\mathrm{w} / \mathrm{v})$ Nuclear Fast Red, coverslipped with Aquamount, and imaged using a Nikon Eclipse TE300 Inverted Microscope, Nikon Digital Sight DS-Ril camera, and NIS-Element Basic Research software.

\section{Protein extractions}

Mouse maxillary and mandibular first molars were extracted from mouse pups at days 5, 11, and 15 using a dissecting microscope. The pulp was removed from the underside of each molar, but the enamel organ epithelium (EOE) was left in place (because some enamel mineral is sometimes removed along with the EOE in the null genotypes). The mineral was rapidly dissolved by submerging the molars in $2 \mathrm{ml}$ of $0.17 \mathrm{M}$ $\mathrm{HCl} / 0.98 \%$ formic acid for $2 \mathrm{~h}$ at $4^{\circ} \mathrm{C}$. Undissolved material was removed by centrifugation at $3,500 \mathrm{~g}$ for $5 \mathrm{~min}$ at $4^{\circ} \mathrm{C}$. The supernatant was adjusted to $\mathrm{pH} \sim 6$ with $50-100 \mu \mathrm{l}$ of $6 \mathrm{M} \mathrm{NaOH}$ (and checked with $\mathrm{pH}$ paper). The samples were then either separated by reverse-phase high-performance liquid chromatography (RP-HPLC) for zymography/western blotting or dialyzed against water overnight and then lyophilized for SDS-PAGE/western blotting. 
The RP-HPLC was run on material extracted from day11 molars in order to separate KLK4 from co-migrating amelogenins that could mask its proteolytic activity on zymograms or antibody binding on western blots. The RPHPLC was run using a Discovery C18 column $(4.6 \mathrm{~mm} \times$ $25 \mathrm{~cm}$; Supelco, Bellefonte, PA, USA) with a $20-75 \%$ gra-

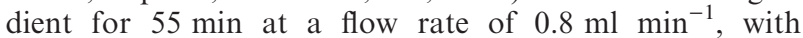
absorbance monitored at $230 \mathrm{~nm}$. Buffer A was $0.05 \%$ trifluoroacetic acid (TFA); buffer B was $80 \%$ acetonitrile and $0.05 \%$ TFA.

\section{SDS-PAGE, western blotting, and zymography}

The amount of protein applied per lane for SDS-PAGE was normalized for each genotype on a per-tooth basis. The number of teeth from each group, their collective weights, the total milligrams of protein extracted, and the micrograms of protein extracted per tooth are provided in Table 1. Lyophilized proteins were weighed and dissolved in $1 \times$ sample buffer $(32 \mathrm{mM}$ Tris- $\mathrm{HCl}, \mathrm{pH} 6.8,13 \%$ glycerol, $1 \%$ SDS, $0.005 \%$ bromophenol blue) to achieve a final concentration of $2 \mu \mathrm{g} \mu \mathrm{l}^{-1}$. Then, $1 \mu \mathrm{l}(2 \mu \mathrm{g})$ was applied in each day-5 lane. The volume applied per lane for the day-11 and day-15 samples of each genotype were adjusted to equal the same percentage of protein per tooth as applied for the day- 5 sample of that genotype, and then fractionated by SDS-PAGE on $12 \%$ or $18 \%$ Tris-glycine gels and stained with Simply Blue Safe Stain (Invitrogen, Carlsbad, CA, USA). Replica gels were transblotted using a Trans-Blot SD semidry transfer cell (BioRad, Hercules, CA, USA) onto Hybond-ECL membranes (GE Healthcare Bio-Sciences, Piscataway, NJ, USA), incubated with blocking solution, immunostained using a primary antibody, then visualized using either the enhanced chemiluminescence (ECL) plus western blotting detection system (GE Healthcare) and exposure of the membrane to hyperfilm ECL (GE Healthcare) for 1 to $3 \mathrm{~min}$, or using colorimetric detection with diaminobenzidine (DAB) that reacts with the anti-rabbit IgG secondary antibody conjugated to horseradish peroxidase (GE Healthcare). The three amelogenin antibodies used were: a polyclonal antibody raised against recombinant mouse amelogenin (rM179) (29), an affinity-purified custom anti-peptide antibody produced by YenZym (San Francisco, CA, USA) against the major mouse amelogenin (M180) Cterminal sequence (C-LEAWPSTDKTKREEVD) encoded by exon 6 , and an affinity-purified anti-peptide antibody raised against a KLH-conjugated alternative C-terminus (C-AFSPMKWYQGMTRHP) encoded by exon 8 (30). Ameloblastin was detected using Ambn-89 (31), an affinitypurified anti-peptide antibody produced by YenZym against the KHL-conjugated peptide MRPREHETQQYEYS, which is near the ameloblastin N-terminus. Kallikrein-related peptidase 4 was detected using affinity-purified antipeptide Igs raised by YenZym against the mouse KLK4 amino acid segment \#85-99 CHNLKGSQEPGSRMLE. Matrix metalloproteinase 20 was detected using a commercial rabbit polyclonal antibody raised against a synthetic peptide corresponding to residues at the human MMP20 (Abcam, Cambridge, MA, USA) C-terminus. The incubation conditions were: rM179 (1:1,000 dilution; overnight incubation); Amel exon 6 (1:10,000 dilution; overnight incubation); Amel exon 8 (1:1,000 dilution; overnight incubation); Ambn-89 (1:1,000 dilution; overnight incubation); KLK4-85 (1:400 dilution; overnight incubation); and MMP20 (1:1,000 dilution; overnight incubation).

Zymograms were run on Novex $12 \%$ casein zymogels (Invitrogen) incubated at $37^{\circ} \mathrm{C}$ for $48 \mathrm{~h}$ in $50 \mathrm{mM}$ Tris- $\mathrm{HCl}$ with either $10 \mathrm{mM}$ calcium (to ensure MMP activity) or with $10 \mathrm{mM}$ EDTA and $1 \mathrm{mM}$ 1,10-phenanthrolin (to inhibit MMP activity).

To detect active KLK4, $1.2 \mathrm{mg}$ of tooth proteins extracted from day-11 wild-type, $M m p 20$ null, and Klk4 null mice were separated by RP-HPLC. Three samples were collected from each run - (i) from 45-50 min, (ii) from 50 to $52.5 \mathrm{~min}$; and (iii) from 52.5 to $55 \mathrm{~min}$ - and lyophilized. The lyophilized samples were each raised in $100 \mu \mathrm{l}$ of $1 \times$ sample buffer and $20 \mu \mathrm{l}$ was applied per lane.

\section{Results}

Enamel proteases are believed to be essential for the removal of proteins so that enamel can achieve its high degree of mineralization $(13,32)$. Our main objective in

Table 1

Data from protein extractions. Proteins were extracted from a minimum of 12 teeth for each genotype/age.

\begin{tabular}{|c|c|c|c|c|}
\hline Mouse age & Wild type & Mmp20 null & Klk4 null & MK Dbl Null \\
\hline \multicolumn{5}{|c|}{ Number (mg wet weight) of teeth extracted } \\
\hline Day 5 & $51(11.59)$ & $46(11.80)$ & $49(9.39)$ & $16(5.2)$ \\
\hline Day 11 & $51(30.67)$ & $52(36.54)$ & $40(34.85)$ & $12(12.4)$ \\
\hline Day 15 & $51(68.29)$ & $53(64.97)$ & $36(45.38)$ & $12(15.2)$ \\
\hline \multicolumn{5}{|c|}{ Milligrams (dry weight) of protein extracted } \\
\hline Day 5 & 1.90 & 1.71 & 1.55 & 0.32 \\
\hline Day 11 & 2.69 & 2.75 & 2.86 & 0.93 \\
\hline Day 15 & 1.10 & 1.96 & 2.32 & 0.88 \\
\hline \multicolumn{5}{|c|}{ Micrograms (dry weight) of protein extracted per tooth } \\
\hline Day 5 & 37.3 & 37.2 & 31.6 & 20 \\
\hline Day 11 & 52.7 & 52.9 & 71.5 & 77.5 \\
\hline Day 15 & 21.2 & 37.0 & 64.4 & 73.3 \\
\hline Analysis & Wild type & Mmp20 null & Klk4 null & MK Dbl Null \\
\hline \multicolumn{5}{|c|}{ Percentage of protein from a single tooth per lane } \\
\hline PAGE/western & 5.3 & 5.3 & 6.3 & 10 \\
\hline Zym/western & 4.6 teeth & 4.5 teeth & 3.4 teeth & - \\
\hline
\end{tabular}

Klk4, kallikrein-related peptidase 4; MK Dbl Null, Klk4/Mmp20 (MK) double-null mice; Mmp20, matrix metalloproteinase 20; western, western blot; Zym, zymogram. 
this study was to characterize and compare accumulated enamel proteins in wild-type, $M m p 20$ null, Klk4 null, and Mmp20/Klk4 double-null mice. First, we compared the retention of enamel proteins histologically in developing maxillary first molars at days 5, 11, and 15 (Fig. 1). At day 5, maxillary first molar ameloblasts are in the secretory stage of amelogenesis, when enamel proteins and MMP20 are secreted and accumulate in the extracellular matrix. Expression of KLK4 has not yet begun $(26,33,34)$. At day 5, enamel proteins are observed throughout the enamel as an eosin-stained layer that is readily identified between the pink dentin and the sheet of ameloblasts. The interface between the ameloblasts and the extracellular matrix is generally linear in the wild-type and Klk4 null mice, but undulating and irregular in the Mmp20 null and Mmp20/Klk4 double-null mice. At day 11, maxillary first-molar ameloblasts are in the maturation stage $(26,33)$, with maturation being more advanced near the cusp tips. All or nearly all ameloblasts are positive for KLK4 expression. At day 11 in the wild-type mice, a thick layer of retained enamel proteins is observed near the cervical margin, but the layer thins and disappears near the cusp tip. The accumulated enamel proteins in the Klk4 and Mmp20 null mice do not appear to have changed from day 5 to day
11. By day 15 , the maturation stage is complete and the maxillary molars are about to erupt into the oral cavity. In wild-type mice the enamel layer is clear - no protein layer is detected. In Klk4 null mice enamel proteins are retained, even at the latest stage when the tooth erupts into the oral cavity. An irregular layer of enamel proteins is observed in both the Mmp20 null and Mmp20/Klk4 double-null mice.

\section{KLK4 expression in Mmp20 null mice}

In Klk4 null mice, the bacterial lac $Z$ gene encoding $\beta$-galactosidase fused to a mouse nuclear localization signal replaced the 5-prime KLK4 protein coding sequence. This permits visualization (by X-gal staining) of expression from the KLK4 promoter in its native context (25). We performed lac $Z$ histochemistry on maxillary first molars from days 5, 8, 11, and 14 wild-type (negative control), Klk4 heterozygous (positive control), and Klk4 heterozygous + Mmp20 null mice (Fig. 2). No background staining was observed in wild-type molars at any day, indicating that lysosomal $\beta$-galactosidase expression was not observed under the incubation time $(5 \mathrm{~h})$ and conditions $(\mathrm{pH}$ 8) used. Klk4 promoter-driven $\beta$-galactosidase activity was observed

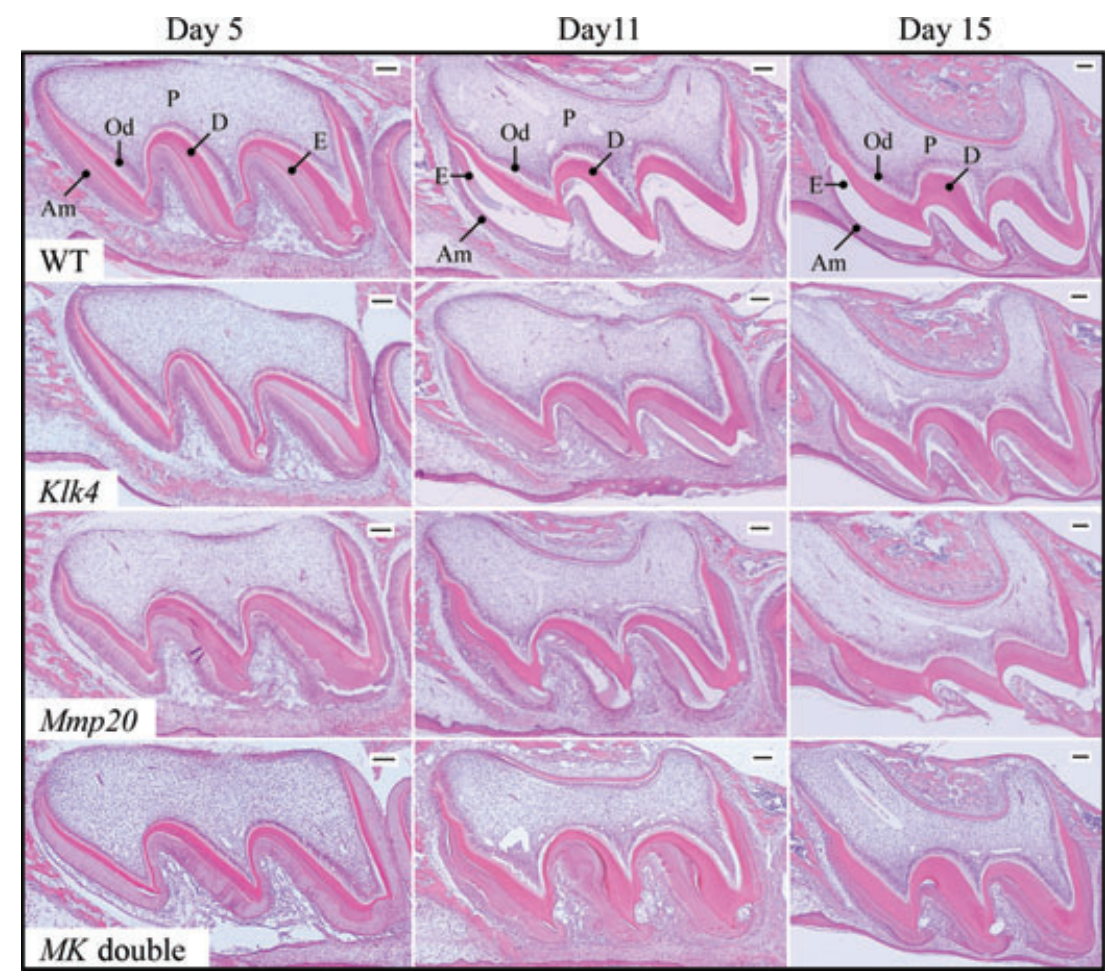

Fig. 1. Histology of maxillary first molars from wild-type, kallikrein-related peptidase 4 (Klk4) null, matrix metalloproteinase 20 (Mmp20) null, and Klk4/Mmp20 (MK) double-null mice from postnatal days 5, 11, and 15. Day 5 (secretory stage): the enamel layers from all four genotypes are protein-rich and stain histologically. The Klk4 null molar is similar to that of the wild-type (WT) mice, while the Mmp20 null and $M K$ double-null molars have irregular enamel layers that vary in thickness. Day 11 (maturation stage): a layer of retained enamel proteins is observed near the cervical margin in wild-type mice (where $\mathrm{E}$ is labeled), but the stained organic matrix thins and disappears near the cusp tip. The Klk4 mice molar shows a uniform thickness of enamel proteins. The Mmp20 null and MK double-null molars have a protein-rich enamel matrix that varies in thickness. Day 15 (near eruption): no protein layer is detected in the wild-type mice (the enamel space is clear, unstained). Proteins are retained throughout the enamel layer in Klk4 null and $M K$ double-null mice. The $M m p 20$ null mouse molar is partially erupted, but a thick layer of protein is still visible in the enamel on the distal surface (left). Am, ameloblasts; D, dentin; E, enamel; Od, odontoblasts; P, pulp. Bars $=100 \mu \mathrm{m}$. 


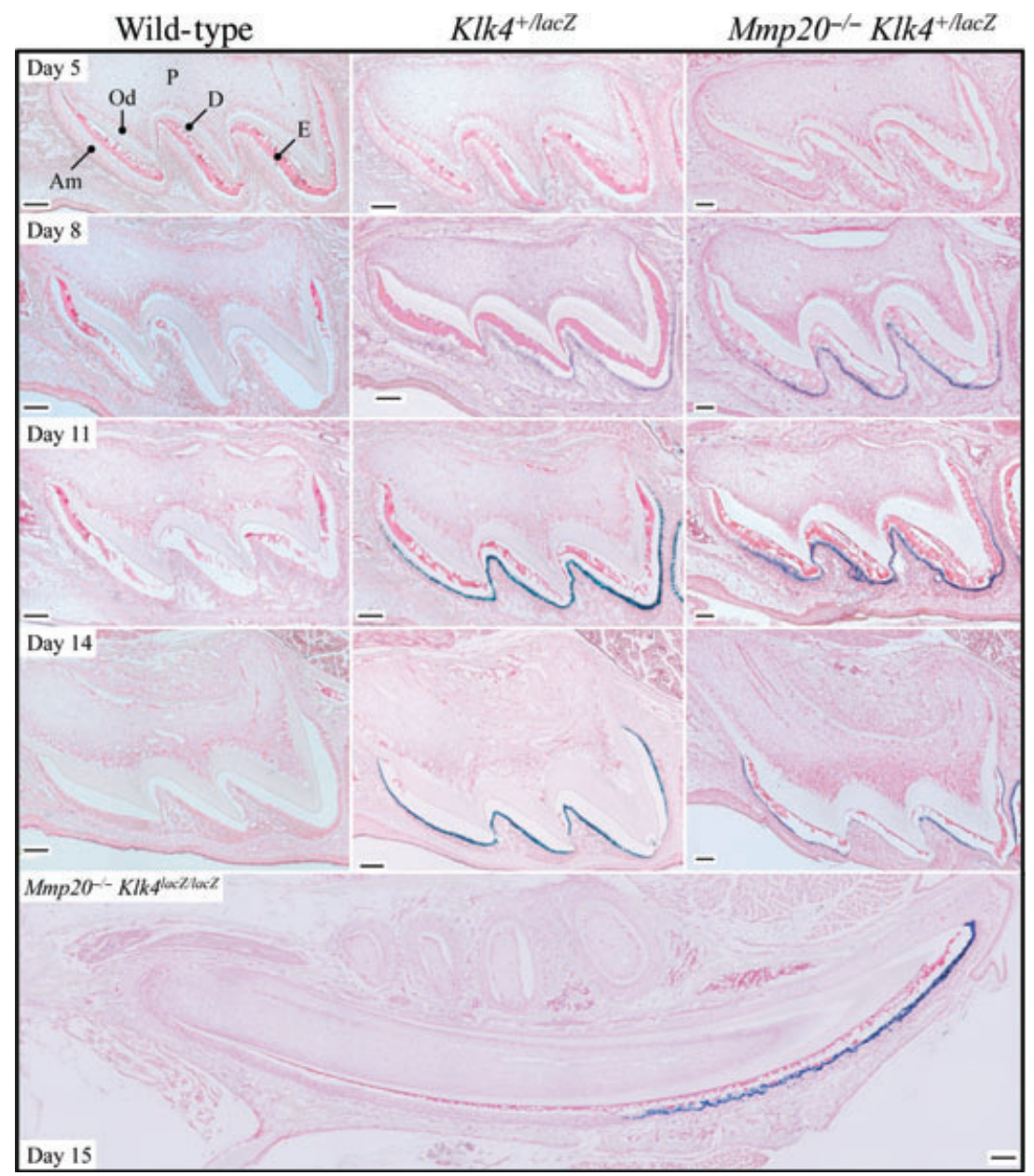

Fig. 2. Kallikrein-related peptidase 4 (KLK4) expression in a day-15 incisor and in maxillary first molars at days $5,8,11$, and 14 in

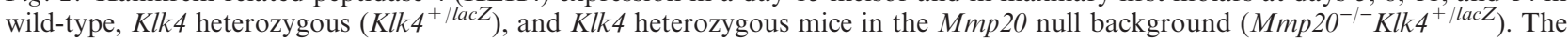
enamel proteins in these sections stain pink. Blue (X-gal) stain marks cells that have expressed LacZ from the Klk4 promoter in the Klk4 knockout/lacZ knockin gene. No background X-gal staining is observed in the wild-type mice. Day 5: abundant enamel proteins are observed in all genotypes and no KLK4 expression in all genotypes. Days 8 and 11: protein levels are diminished near the cusp tips in the wild-type; and X-gal staining in the mice expressing Klk4 $4^{+ \text {llac Z }}$ is observed on the cusp tips and slopes. Day 14: X-gal staining in the mice expressing Klk4 $4^{+/ l a c Z}$ is observed throughout the ameloblast layer. Enamel proteins have cleared entirely from the wild-type and mostly from the $\mathrm{Klk} 4^{+/ l a c Z}$ molars in the wild-type background, but remain in the Mmp20 null condition, particularly over the dentin surface. Day 15: longitudinal section through the mandibular incisor from an Mmp20 + Klk4 doublenull mouse $\left(\mathrm{Mmp} 2 \mathrm{O}^{-/-} \mathrm{Klk} 4^{\text {lac Z/lac Z }}\right)$. Secretory ameloblasts are negative for KLK4 expression; transition and maturation ameloblasts are positive. Enamel protein is observed throughout the enamel layer all the way to the tip of the cusp. Am, ameloblasts; D, dentin; E, enamel; Od, odontoblasts; P, pulp. Bars $=100 \mu \mathrm{m}$.

specifically in maturation ameloblasts on days 8,11 , and 14 , in Klk4 heterozygous mice in both the wild-type and Mmp20 null backgrounds. Retained enamel proteins (stained red) were not detected in the wild-type maxillary first molars at day 14 , but were observed in the same molars in the Mmp20 null background, particularly near the cervical margin and near the dentin surface. $L a c Z$ histochemistry was also performed on a mandible from a day-15 Mmp20/Klk4 double-null mouse. In the longitudinally sectioned incisor, positive $\mathrm{X}$-gal staining was strongly and specifically observed in maturation ameloblasts, which exactly matches previous characterizations of Klk4 expression in wild-type mice by in situ hybridization (33-35) and in Mmp20 null mice by PCR amplification (36).
Matrix metalloproteinase 20 can activate the KLK4 zymogen in vitro, but it is not known if $M m p 20$ is required for KLK4 activation in vivo (20). Taking advantage of the late elution of KLK4 relative to other enamel proteins on RP-HPLC, we analyzed day-11 maxillary first molar proteins with a retention time near 50 min from wild-type (positive control), Mmp20 null, and Klk4 null mice (Fig. 3). An active KLK4 doublet was observed by casein zymography and western blotting in both the wild-type and Mmp20 null mice, but not in Klk4 null mice. The intensity of the KLK4 bands was lower in the Mmp20 null mice relative to the wild-type mice. This demonstrates that KLK4 is activated in vivo in the absence of MMP20. At present, not much significance is attached to the reduced amount of KLK4 in the 


\section{A Wild-type}
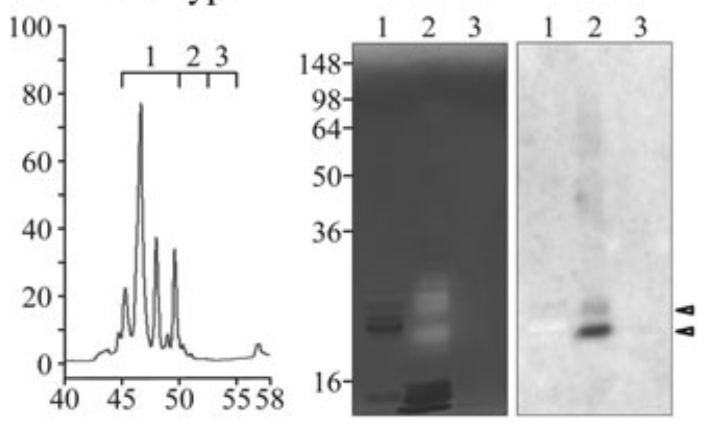

\section{B $\quad$ Mmp20 null}
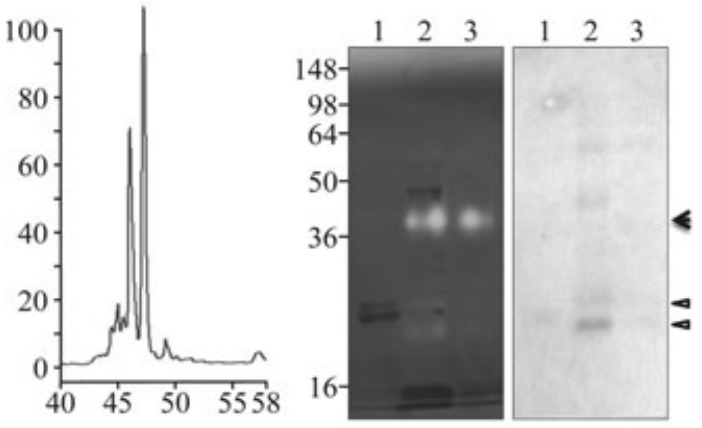

\section{c Klk4 null}
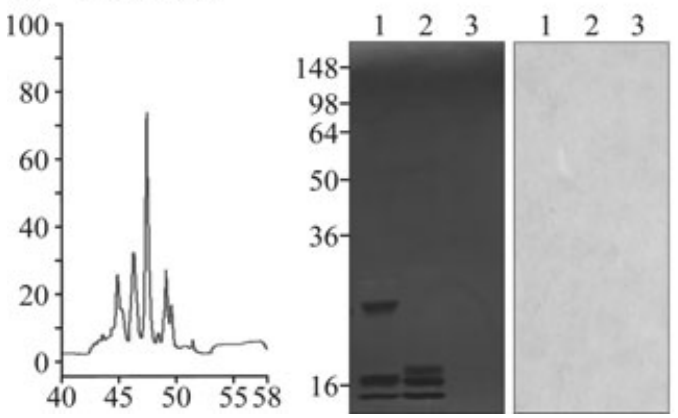

Fig. 3. Kallikrein-related peptidase 4 (KLK4) in Mmp20 null mice. Kallikrein-related peptidase 4 elutes from a reverse-phase high-performance liquid chromatography (RP-HPLC) column between 50 and $52.5 \mathrm{~min}$. Left: enamel proteins $(1.2 \mathrm{mg})$ from wild-type, Mmp20 null, and Klk4 null mice were fractionated by RP-HPLC and three fractions were collected, from (i) 45$50 \mathrm{~min}$, (ii) $50.0-52.5 \mathrm{~min}$, and (iii) 52.5-55.0 min. Right: zymography and western blot analyses of the three fractions. Active KLK4 was detected in the Mmp20 null mice migrating as a doublet. An unknown proteolytic activity migrating at $40 \mathrm{kDa}$ was observed only in the Mmp20 null mice. Triangles indicate KLK4 bands; the arrowhead marks an unidentified 40$\mathrm{kDa}$ protease.

Mmp20 null molars. The KLK4 samples applied to the gel from the wild-type and $M m p 20$ null mice were from an equivalent number of teeth ( $\sim 4.5$ molars $)$, but the mineral layer covering dentin is smaller in Mmp20 null mice relative to the wild-type mice, so the apparent reduction in KLK4 activity in the Mmp20 null condition might reflect the general reduction in matrix volume per tooth. An unexpected discovery in the Mmp20 null mice was the expression of a $40-\mathrm{kDa}$ protease that was not expressed in the wild-type or Klk4 null mice.

\section{MMP20 expression in Klk4 null mice}

To characterize MMP20 activity in Klk4 null mice, we analyzed first molar (maxillary and mandibular) protein samples from days 5,11 , and 15 by western blotting with antibodies to MMP20 as well as by zymography with and without inhibitors of MMPs (Fig. 4). Matrix metalloproteinase 20 bands were observed as expected in the secretory and early-maturation stages in wild-type mice; however, MMP20 activity persisted in the Klk4 null mice all the way to day 15 . This finding suggests that KLK4 might degrade MMP20 in vivo. The zymogram from the Mmp20 null mice showed an absence of MMP20 and demonstrated that the 40-kDa unidentified protease is up-regulated specifically in the maturation stage of Mmp20 null mice, and that this protease is not inactivated by EDTA or phenanthroline (indicating that it is not an MMP). The MMP20 knockout deleted most of intron 4 and all of exon 5, but skipping exon 5 during RNA splicing would not shift the reading frame and might generate an inactive form of MMP20 lacking the exon 5-encoded segment (23). No such protein was detected in the extracts from Mmp20 null mouse using the MMP20 C-terminal antibody, so the Mmp20 knockout appears to be a true knockout (absence of protein) and not simply a loss-of-function model.

Matrix metalloproteinase 20 was readily detected in wild-type samples containing matrix from only $5 \%$ of a single day-5 or day-11 molar, whereas KLK4 was concentrated by RP-HPLC and detected in a sample derived from 4.5 teeth, suggesting that MMP20 might be 100 -fold more abundant than KLK4 in developing mouse enamel. However, this difference is probably because of the greater sensitivity of casein zymograms to detect MMP20 relative to KLK4 and a more sensitive antibody for detecting MMP20 on western blots. When extracting these enzymes from pig molars in the crownformation stage, our yields of MMP20 are only about twice those of KLK4.

\section{Residual enamel proteins}

Alternative splicing generates many mouse amelogenin isoforms $(30,37-40)$, but only two ameloblastin isoforms $(41,42)$. During the secretory stage, MMP20 initially cleaves amelogenin near its carboxyl end (17, 43, 44), while MMP20 initially cleaves ameloblastin near its amino end $(18,19,45,46)$. In the absence of proteolytic processing, an amelogenin C-terminal antibody and an ameloblastin $\mathrm{N}$-terminal antibody would detect the intact secreted proteins, with multiple bands being caused by alternative splicing. We analyzed accumulated enamel proteins from wild-type, Mmp20 null, Klk4 null, and $M m p 20 / K l k 4$ double-null first molars at days 5, 11, and 15 by SDS-PAGE and by western blotting using antibodies raised against full-length recombinant amelogenin (rM179), two alternative amelogenin C-terminal peptides, and an ameloblastin near the N-terminal peptide (Fig. 5).

The day-5 enamel proteins from wild-type and Klk4 null mice showed virtually identical patterns of amelo- 
A Wild-type
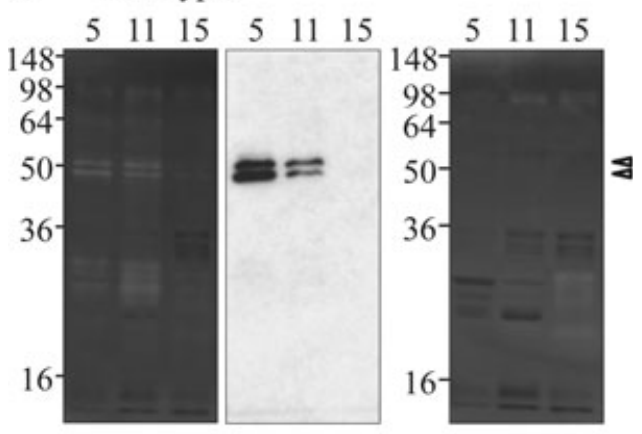

B Mmp20 null
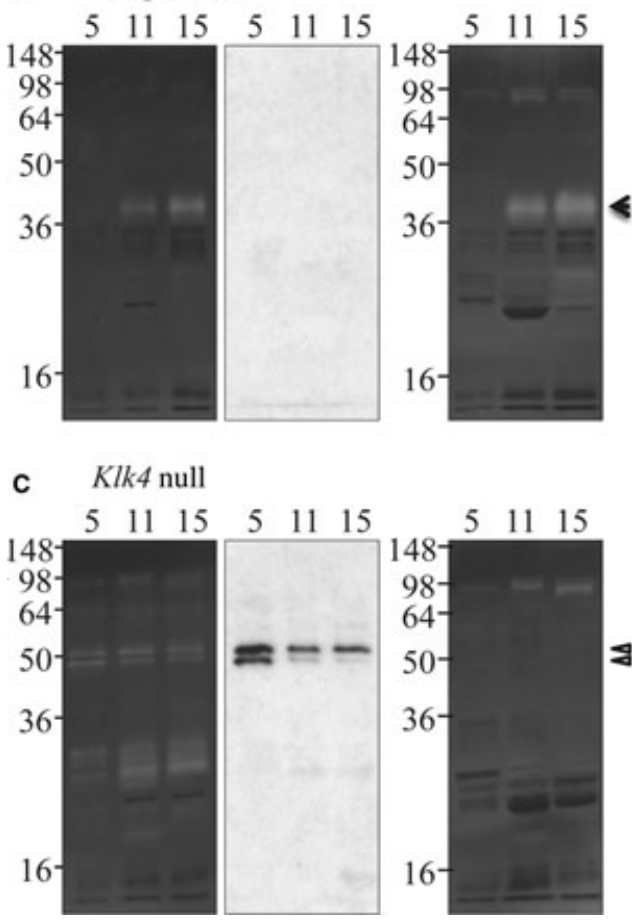

Fig. 4. Matrix metalloproteinase 20 (MMP20) in kallikreinrelated peptidase 4 (Klk4) null mice. Matrix metalloproteinase 20 is easily detected on casein zymograms and western blots. Enamel proteins from days $5(2 \mu \mathrm{g}), 11$, and 15 were analyzed on casein zymograms with calcium (left) or with EDTA and phenanthroline (MMP inhibitors) (right), and by western blotting (center) using an MMP20 C-terminal antibody. Matrix metalloproteinase 20 was not detected in the Mmp20 null mice. Day 5: MMP20 was detected in wild-type and Klk4 null mice as a doublet near $50 \mathrm{kDa}$, but not on zymograms incubated with MMP inhibitors. The MMP20 catalytic domain was responsible for a group of caseinolytic bands around $30 \mathrm{kDa}$. Day 11: MMP20 was detected in wild-type and Klk4 null mice. An unidentified $40-\mathrm{kDa}$ protease was evident in the Mmp20 null mice and was active in the presence of MMP inhibitors. Day 15: MMP20 was only detected in the Klk4 null mice. The 40-kDa protease was also detected. Triangles indicate MMP20 bands and the arrowhead indicates an unidentified $40-\mathrm{kDa}$ protease.

genin bands using the rM179 antibody. The lowermolecular-mass amelogenins $(\sim 14-22 \mathrm{kDa})$ were not detected with either of the amelogenin C-terminal antibodies and must be cleavage products. The Mmp20 null and Mmp20/Klk4 double-null mice also produced identical amelogenin patterns using the rM179 antibody.
Importantly, all of the amelogenin bands in the Mmp20 null mice co-migrate with bands also detected by the C-terminal antibodies. No amelogenin cleavage products were detected in the day-5 (secretory stage) matrix of mice lacking MMP20.

Day-5 enamel proteins from wild-type and Klk4 null first molars both contained a $17-\mathrm{kDa}$ ameloblastin cleavage product that was strongly detected by the ameloblastin near N-terminal antibody. In contrast, the day-5 enamel proteins from the Mmp20 null and Mmp20/Klk4 doublenull first molars both showed an ameloblastin doublet of around 65 and $50 \mathrm{kDa}$. These two bands are consistent with being the 396- and 381-amino-acid O-glycosylated ameloblastin isoforms expressed from alternatively spliced mRNA transcripts. Based upon the mouse ameloblastin cDNA sequences and characterization of the pig ameloblastin protein (47), the smaller ameloblastin has 15 fewer amino acids and lacks one potential O-linked glycosylation relative to the larger isoform. These findings show that MMP20 cleaves ameloblastin to generate a 17-kDa product that is detected by the Ambn- 89 antibody. The data also support the interpretation that MMP20 further degrades this $17-\mathrm{kDa}$ protein based upon the presence of smaller immunopositive bands and the diminishing of this product in the day-11 molars of the KLK4 null mice (where MMP20 is the only enamel protease). The day-5 data strongly support previous conclusions that MMP20 is the only major proteolytic activity in secretory-stage enamel.

By day 15, enamel proteins have been virtually removed from the matrix in wild-type mouse first molars. When MMP20, KLK4, or both enzymes are missing from the matrix, high-molecular-weight uncleaved enamel proteins are retained in the enamel layer. Kallikrein-related peptidase 4 is not able to compensate for the absence of MMP20 in Mmp20 null mice, and highmolecular-weight amelogenins are retained in the matrix. Kallikrein-related peptidase 4 degrades some of the intact enamel proteins that accumulate in the absence of MMP20, as the retention of enamel proteins is clearly increased in the Mmp20/Klk4 double-null mice when compared with Mmp20 null mice. Similarly, continued expression of MMP20 during the maturation stage cannot compensate for the absence of KLK4. The effects of MMP20 activity during the maturation stage are evident in the Klk4 null mice by the reduced amounts of intact amelogenins recognized by the $\mathrm{C}$-terminal antibodies and by the loss of the $17-\mathrm{kDa}$ ameloblastin from the matrix as maturation progresses to day 15. Although the full-length amelogenins diminish during the maturation stage in the Klk4 null mice, the cleaved products appear to remain as the pattern of accumulated amelogenins in enamel matrix recognized by the rM179 antibody does not change appreciably after the secretory stage.

\section{Discussion}

Substantial evidence supports the conclusion that MMP20 is the predominant, if not the exclusive, extracellular protease in secretory-stage enamel. Matrix me- 


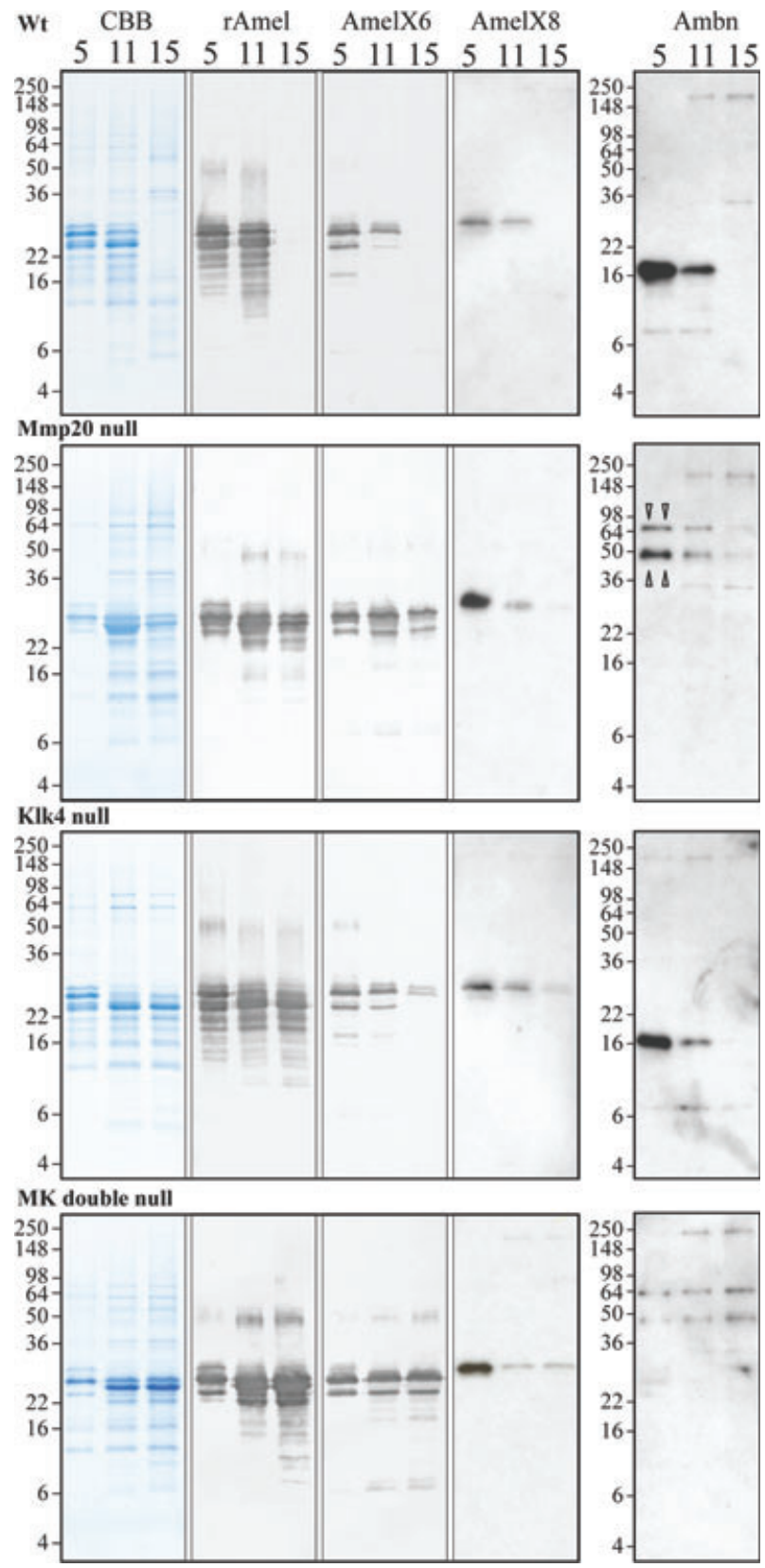

Fig. 5. SDS-PAGE and western blot analyses of amelogenin and ameloblastin at days 5, 11, and 15 from wild-type (Wt), matrix metalloproteinase 20 (Mmp20) null, kallikrein-related peptidase 4 (Klk4) null, and Mmp20/Klk4 (MK) double-null mice. Panels show (from left to right): Coomassie Brilliant Blue-stained SDS-polyacrylamide gels; western blots with rM179 antibody (rAmel); western blots with amelogenin C-terminal antibodies specific for the exon 6-encoded sequence (AmelX6) and for the exon 8-encoded sequence (AmelX8); and western blots with the ameloblastin (Ambn) antibody for the N-terminal domain. All day-5 lanes show $2-\mu \mathrm{g}$ loads. Day-11 and day-15 lanes from each genotype show the same percentage of protein per tooth (see Table 1). Bands on western blots using amelogenin C-terminal antibodies are uncleaved amelogenin isoforms. Note: all amelogenin-positive bands in the day-5 MMP20 null and MK double-null mice co-migrate with intact amelogenin and the wild-type and Klk4 null samples are identical at day 5 (secretory stage). Two bands at 65 and $50 \mathrm{kDa}$ in Mmp20 null and MK double-null mice are likely to be uncleaved ameloblastin (triangle pointers). All positive bands of $\sim 200 \mathrm{kDa}$ are immunoglobulins that were also detected in controls using only the secondary antibody (data not shown).

talloproteinase 20 has been shown to be expressed by secretory-stage ameloblasts by in situ hybridization (33, $35,48)$ and immunohistochemistry $(49,50)$. Matrix metalloproteinase 20 is readily isolated from developing pig enamel scrapings as a doublet migrating at 41 and $46 \mathrm{kDa}$ on SDS-PAGE and casein zymograms $(49,51)$.
Enamel protein cleavage products have been isolated from developing pig enamel, and the cleavage sites that generated them from parent proteins have been characterized. Matrix metalloproteinase 20 cleaves amelogenin and ameloblastin in vitro at exactly the same sites as in vivo (16-19). Furthermore, MMP20 has low activity 
against the major cleavage products that accumulate to abundance in secretory-stage enamel, such as the tyrosine- and leucine-rich amelogenin peptides (TRAP and LRAP, respectively) $(17,52)$ and the $32-\mathrm{kDa}$ enamelin (53). Here we demonstrate that the accumulated enamel matrix of secretory-stage mouse molars in Mmp20 null and Mmp20/Klk4 double-null mice comprises highermolecular-weight intact amelogenin isoforms that retain their original C-terminal peptides. Absent from the matrix are lower-molecular-weight amelogenin cleavage products that are observed in the wild-type and Klk4 null mice. We also observed protein bands that probably correspond to the two ameloblastin-secreted isoforms in the Mmp20 null and Mmp20/Klk4 double-null mice. These ameloblastins were absent from both the wild-type and Klk4 null mice that express MMP20 and in their place was a $17-\mathrm{kDa}$ ameloblastin cleavage product that is similar in size to a porcine ameloblastin cleavage product from the same part of the protein (46). These findings strongly support the conclusion that MMP20 is the predominant protease in secretory-stage enamel and that no other matrix protease contributes significantly to the hydrolysis of secreted enamel proteins during the secretory stage.

In addition to the substantial evidence demonstrating that MMP20 is the predominant secretory-stage enamel protease, there is additional strong evidence that KLK4 is not expressed or secreted into secretory-stage enamel, but is solely expressed and secreted into the enamel matrix by transition and maturation-stage ameloblasts. Active KLK4 enzyme is readily isolated from developing pig teeth, and its ability to cleave enamel proteins in vitro has been determined experimentally. Kallikreinrelated peptidase 4 cleaves amelogenin at many sites, and the positions of the cleavage sites are complementary to those of MMP20 (20). Kallikrein-related peptidase 4 cleaves at many sites on the $\mathrm{N}$-terminal side of amelogenin. If present during the secretory stage, KLK4 would hydrolyze the relatively stable amelogenin-cleavage products that normally accumulate in enamel and lead to an altered pattern of residual amelogenins, which is not observed. Klk4 mRNA has been shown by in situ hybridization to initially appear in transitionstage ameloblasts (33-35). This finding has been supported by X-gal histochemistry in Klk4 knockout/lacZ knockin mice $(26,54)$ and by immunohistochemistry (55). Kallikrein-related peptidase 4 in situ hybridization sometimes showed a weak signal in odontoblasts, which supports the hypothesis that KLK4 might be secreted through odontoblastic processes into the deep enamel at the DEJ (56). However, X-gal histochemistry results clearly show only trace, sporadic expression of KLK4 by odontoblasts that could not be sufficient to influence protein accumulation in enamel. The enamel in Klk4 null mice, although hypomineralized, was as thick as enamel in wild-type mice and had normal rod architecture, indicating proper secretory-stage development (25). In this study we present SDS-PAGE and western blot analyses which show that the accumulated amelogenin and ameloblastin proteins in day-5 (secretory stage) molars are identical in wild-type and Klk4 null mice. In the Klk4 null mice the accumulated enamel proteins in late maturation (day 15) look the same as those in the secretory stage (day 5). In contrast, there are no residual amelogenin or ameloblastin proteins in the day-15 wild-type mice. These results strongly support the conclusion that KLK4 is the predominant matrix protease in the maturation stage and that no other maturation-stage enzyme is able to digest enamel proteins in a way that facilitates their efficient removal from the matrix.

Analysis of the proteins and proteases in MMP20and/or KLK4-deficient mice yielded several surprises. The first was finding a $40-\mathrm{kDa}$ protease in maturationstage tooth extracts specifically when MMP20 is lacking. The identity of this protease is currently under investigation. Its presence may be part of a response by ameloblasts to the faulty array of inputs they receive from the defective extracellular matrix. Perhaps understanding its induction could provide information about normal feedback mechanisms that allow ameloblasts to adjust to the dynamic requirements of enamel deposition.

We have shown that KLK4 is active in the absence of MMP20 and conversely that MMP20 is active in the absence of KLK4. Matrix metalloproteinase 20 may persist for longer in the matrix in the absence of KLK4. The activity of MMP20 during the maturation stage may help to explain why the superficial enamel hardens to near-normal levels in Klk4 null mice. If so, this would represent the full extent of the functional overlap of the two enzymes. There may also be some functional synergy. By day 15 in wild-type mice, KLK4 was able to clear a large amount of enamel proteins that had accumulated by day 11 . In contrast, KLK4 was not able to clear the uncleaved enamel proteins that had accumulated in the Mmp20 null mice. Perhaps KLK4 is less efficient at cleaving intact enamel proteins in vivo (although it readily cleaves full-length amelogenin or ameloblastin in vitro) or has trouble accessing enamel proteins in the disorganized matrix that forms in the absence of MMP20. However, KLK4 certainly cleaves some enamel proteins in the absence of MMP20. When both enzymes are absent, the level of accumulated enamel proteins is higher than when either of the enzymes alone is missing. In the double-null mouse at the time of eruption (day 15) there appears to be even more organic matrix than earlier in the maturation stage (day 11).

Acknowledgements -This investigation was supported by USPHS Research Grants DE015846, DE019775, and DE016276 from the National Institute of Dental and Craniofacial Research, National Institutes of Health, Bethesda, MD 29892, USA.

Conflicts of interest - All authors declare that there are no competing interests.

\section{References}

1. Ronnholm E. The amelogenesis of human teeth as revealed by electron mircoscopy I. The fine structure of the ameloblasts. J Ultrastruct Res 1962; 6: 229-248. 
2. Boyde A. The development of enamel structure. Proc $R$ Soc Med 1967; 60: 923-928.

3. Sмith CE. Cellular and chemical events during enamel maturation. Crit Rev Oral Biol Med 1998; 9: 128-161.

4. Smith CE, Pompura JR, Borenstein S, Fazel A, Nanci A. Degradation and loss of matrix proteins from developing enamel. Anat Rec 1989; 224: 292-316.

5. Nanci A, Slavkin HC, Smith CE. Application of high-resolution immunocytochemistry to the study of the secretory, resorptive, and degradative functions of ameloblasts. Adv Dent Res 1987; 1: 148-161.

6. Nanci A, Slavkin HC, Smith CE. Immunocytochemical and radioautographic evidence for secretion and intracellular degradation of enamel proteins by ameloblasts during the maturation stage of amelogenesis in rat incisors. Anat Rec 1987; 217: 107-123.

7. Sмith CE. Ameloblasts: secretory and resorptive functions. $J$ Dent Res 1979; 58: 695-707.

8. Bartlett JD, Simmer JP, Xue J, Margolis HC, Moreno EC. Molecular cloning and mRNA tissue distribution of a novel matrix metalloproteinase isolated from porcine enamel organ. Gene 1996; 183: 123-128.

9. Simmer JP, Fukae M, Tanabe T, Yamakoshi Y, Uchida T, Xue J, Margolis HC, Shimizu M, DeHart BC, Hu CC, BARTLETT JD. Purification, characterization, and cloning of enamel matrix serine proteinase 1. J Dent Res 1998; 77: 377386.

10. Kim JW, Simmer JP, Hart TC, Hart PS, Ramaswami MD, BARTLETT JD, Hu JC. MMP-20 mutation in autosomal recessive pigmented hypomaturation amelogenesis imperfecta. J Med Genet 2005; 42: 271-275.

11. Hart PS, Hart TC, Michalec MD, Ryu OH, Simmons D, Hong S, Wright JT. Mutation in kallikrein 4 causes autosomal recessive hypomaturation amelogenesis imperfecta. $J$ Med Genet 2004; 41: 545-549.

12. Fukae M, Yamamoto R, Karakida T, Shimoda S, Tanabe T. Micelle structure of amelogenin in porcine secretory enamel. J Dent Res 2007; 86: 758-763.

13. Bartlett JD, Simmer JP. Proteinases in developing dental enamel. Crit Rev Oral Biol Med 1999; 10: 425-441.

14. Simmer JP, Hu JC. Expression, structure, and function of enamel proteinases. Connect Tissue Res 2002; 43: 441449.

15. Lu Y, Papagerakis P, Yamakoshi Y, Hu JC, Bartlett JD, SIMMER JP. Functions of KLK4 and MMP-20 in dental enamel formation. Biol Chem 2008; 389: 695-700.

16. Ryu OH, Fincham AG, Hu CC, Zhang C, Qian Q, Bartlett JD, SimMER JP. Characterization of recombinant pig enamelysin activity and cleavage of recombinant pig and mouse amelogenins. J Dent Res 1999; 78: 743-750.

17. Nagano T, Kakegawa A, Yamakoshi Y, Tsuchiya S, Hu JC, Gomi K, Arai T, Bartlett JD, Simmer JP. Mmp-20 and Klk4 cleavage site preferences for amelogenin sequences. J Dent Res 2009; 88: 823-828.

18. Inata T, Yamakoshi Y, Hu JC, Ishikawa I, Bartlett JD, Krebsbach PH, Simmer JP. Processing of ameloblastin by MMP-20. J Dent Res 2007; 86: 153-157.

19. Chun YH, Yamakoshi Y, Yamakoshi F, Fukae M, Hu JC, Bartlett JD, Simmer JP. Cleavage site specificity of MMP-20 for secretory-stage ameloblastin. J Dent Res 2010; 89: 785790 .

20. Ryu O, Hu JC, Yamakoshi Y, Villemain JL, Cao X, Zhang C, Bartlett JD, Simmer JP. Porcine kallikrein-4 activation, glycosylation, activity, and expression in prokaryotic and eukaryotic hosts. Eur J Oral Sci 2002; 110: 358-365.

21. Ryu OH, Hu CC, Simmer JP. Biochemical characterization of recombinant mouse amelogenins: protein quantitation, proton absorption, and relative affinity for enamel crystals. Connect Tissue Res 1998; 38: 207-214.

22. Sun Z, Fan D, Fan Y, Du C, Moradian-Oldak J. Enamel proteases reduce amelogenin-apatite binding. J Dent Res 2008; 87: 1133-1137.

23. Caterina JJ, Skobe Z, Shi J, Ding Y, Simmer JP, BirkedalHansen H, Bartlett JD. Enamelysin (matrix metalloprotein- ase 20)-deficient mice display an amelogenesis imperfecta phenotype. J Biol Chem 2002; 277: 49598-49604.

24. Bartlett JD, Beniash E, Lee DH, Smith CE. Decreased mineral content in MMP-20 null mouse enamel is prominent during the maturation stage. J Dent Res 2004; 83: 909-913.

25. Simmer JP, Hu Y, Lertlam R, Yamakoshi Y, Hu JC. Hypomaturation enamel defects in Klk4 knockout/LacZ knockin mice. J Biol Chem 2009; 284: 19110-19121.

26. Simmer J, Hu Y, Richardson A, Bartlett J, Hu JC-C. Why does enamel in Klk4 null mice break above the dentino-enamel junction? Cells Tissues Organs 2011; 194: 211-215.

27. Smith CE, Richardson AS, Hu Y, Bartlett JD, Hu JC, Simmer JP. Effect of kallikrein 4 loss on enamel mineralization: comparison with mice lacking matrix metalloproteinase 20 . J Biol Chem 2011; 286: 18149-18160.

28. Bronckers AL, Lyaruu DM, Jansen ID, Medina JF, KellOKumpu S, Hoeben KA, Gawenis LR, Oude-Elferink RP, EVERTS V. Localization and function of the anion exchanger Ae2 in developing teeth and orofacial bone in rodents. $J$ Exp Zool B Mol Dev Evol 2009; 10: 10.

29. Simmer JP, lau EC, Hu CC, Aoba T, Lacey M, Nelson D, Zeichner-David M, Snead ML, Slavkin HC, Fincham AG. Isolation and characterization of a mouse amelogenin expressed in Escherichia coli. Calcif Tissue Int 1994; 54: 312-319.

30. Bartlett JD, Ball RL, Kawai T, Tye CE, Tsuchiya M, SimMER JP. Origin, splicing, and expression of rodent amelogenin exon 8. J Dent Res 2006; 85: 894-899.

31. Chun YH, Lu Y, Hu Y, Krebsbach PH, Yamada Y, Hu JC, SIMMER JP. Transgenic rescue of enamel phenotype in Ambn null mice. J Dent Res 2010; 89: 1414-1420.

32. Suga S. Histochemical observation of proteolytic enzyme activity in the developing dental hard tissues of the rat. Arch Oral Biol 1970; 15: 555-558.

33. Hu JC, Sun X, Zhang C, Liu S, Bartlett JD, Simmer JP. Enamelysin and kallikrein-4 mRNA expression in developing mouse molars. Eur J Oral Sci 2002; 110: 307-315.

34. Hu JC, Zhang C, Sun X, Yang Y, CaO X, Ryu O, Simmer JP. Characterization of the mouse and human PRSS17 genes, their relationship to other serine proteases, and the expression of PRSS17 in developing mouse incisors. Gene 2000; 251: $1-8$.

35. Simmer JP, Sun X, Yamada Y, Zhang CH, Bartlett JD, Hu JC-C. Enamelysin and kallikrein-4 expression in the mouse incisor. In: Kobayashi I, Ozawa H, eds. Biomineralization: formation, diversity, evolution and application Proceedings of the 8th International Symposium on Biomineralization, Niigata, Japan, Sept 25-28, 2001. Hadano, Japan: Tokai University Press, 2004; 348-352.

36. Tye Ce, Sharma R, Smith CE, Bartlett JD. Altered ionresponsive gene expression in Mmp20 null mice. $J$ Dent Res 2009; 89: $1421-1426$

37. Lau EC, Simmer JP, Bringas P, Hsu D, Hu CC, ZeichnerDavid M, Thiemann F, Snead ML, Slavkin HC, Fincham AG. Alternative splicing of the mouse amelogenin primary RNA transcript contributes to amelogenin heterogeneity. Biochem Biophys Res Commun 1992; 188: 1253-1260.

38. Simmer JP. Alternative splicing of amelogenins. Connect Tissue Res 1995; 32: 131-136.

39. Hu CC, Ryu OH, Qian Q, Zhang CH, Simmer JP. Cloning, characterization, and heterologous expression of exon-4containing amelogenin mRNAs. J Dent Res 1997; 76: 641647.

40. Li W, Mathews C, Gao C, DenBesten PK. Identification of two additional exons at the $3^{\prime}$ end of the amelogenin gene. Arch Oral Biol 1998; 43: 497-504.

41. Krebsbach PH, Lee SK, Matsuki Y, Kozak CA, Yamada K, YAMADA Y. Full-length sequence, localization, and chromosomal mapping of ameloblastin: a novel tooth-specific gene. J Biol Chem 1996; 271: 4431-4435.

42. Hu CC, Fukae M, Uchida T, Qian Q, Zhang CH, Ryu OH, Tanabe T, Yamakoshi Y, Murakami C, Dohi N, Shimizu M, SimMER JP. Sheathlin: cloning, cDNA/polypeptide sequences, and immunolocalization of porcine enamel sheath proteins. $J$ Dent Res 1997; 76: 648-657. 
43. Fincham aG, Moradian-Oldak J. Amelogenin post-translational modifications: carboxy-terminal processing and the phosphorylation of bovine and porcine "TRAP" and "LRAP" amelogenins. Biochem Biophys Res Commun 1993; 197: 248255.

44. Fincham AG, Moradian-Oldak J. Comparative mass spectrometric analyses of enamel matrix proteins from five species suggest a common pathway of post-secretory proteolytic processing. Connect Tissue Res 1996; 35: 151-156.

45. Uchida T, Murakami C, Wakida K, Dohi N, Iwai Y, Simmer JP, Fukae M, Satoda T, Takahashi O. Sheath Proteins: synthesis, secretion, degradation and fate in forming enamel. Eur J Oral Sci 1998; 106: 308-314.

46. Fukae M, Kanazashi M, Nagano T, Tanabe T, Oida S, Gom $\mathrm{K}$. Porcine sheath proteins show periodontal ligament regeneration activity. Eur J Oral Sci 2006; 114 (Suppl 1): 212 218.

47. Kobayashi K, Yamakoshi Y, Hu JC, Gomi K, Arai T, Fukae M, Krebsbach PH, Simmer JP. Splicing determines the glycosylation state of ameloblastin. J Dent Res 2007; 86: 962967.

48. Begue-Kirn C, Krebsbach PH, Bartlett JD, Butler WT. Dentin sialoprotein, dentin phosphoprotein, enamelysin and ameloblastin: tooth-specific molecules that are distinctively expressed during murine dental differentiation. Eur J Oral Sci 1998; 106: 963-970.

49. Fukae M, Tanabe T, Uchida T, Lee SK, Ryu OH, Murakami C, Wakida K, Simmer JP, Yamada Y, Bartlett JD. Enamelysin (matrix metalloproteinase-20): localization in the devel- oping tooth and effects of $\mathrm{pH}$ and calcium on amelogenin hydrolysis. J Dent Res 1998; 77: 1580-1588.

50. Bourd-Boittin K, Septier D, Hall R, Goldberg M, MenASHI S. Immunolocalization of enamelysin (matrix metalloproteinase-20) in the forming rat incisor. J Histochem Cytochem 2004; 52: 437-445.

51. Yamada Y, Yamakoshi Y, Gerlach R, Hu C, Matsumoto K, Fukae M, Oida S, Bartlett J, Simmer J. Purification and characterization of enamelysin from secretory stage pig enamel. Arch Comp Biol Tooth Enam 2003; 8: 21-25.

52. Fincham AG, Belcourt AB, Termine JD, Butler WT, Cothran WC. Dental enamel matrix: sequences of two amelogenin polypeptides. Biosci Rep 1981; 1: 771-778.

53. Yamakoshi Y, Hu JC-C, Fukae M, Iwata T, Simmer JP. How do MMP-20 and KLK4 process the $32 \mathrm{kDa}$ enamelin? Eur $J$ Oral Sci 2006; 114 (Suppl 1): 45-51.

54. Simmer J, Richardson A, Smith C, Hu Y, Hu J-C. Expression of kallikrein 4 in dental and non-dental tissues. Eur J Oral Sci 2011; 119 (Suppl. 1): 226-233.

55. Hu JC, Ryu OH, Chen JJ, Uchida T, Wakida K, Murakami C, Jiang H, Qian Q, Zhang C, Ottmers V, Bartlett JD, SIMMER JP. Localization of EMSP1 expression during tooth formation and cloning of mouse cDNA. J Dent Res 2000; 79: 70-76.

56. Fukae M, Tanabe $\mathrm{T}$, Nagano $\mathrm{T}$, Ando $\mathrm{H}$, Yamakoshi $\mathrm{Y}$, YAMADA M, SIMMER JP, OIDA S. Odontoblasts enhance the maturation of enamel crystals by secreting EMSP1 at the enamel-dentin junction. $J$ Dent Res 2002; 81: 668672. 